\title{
Whodunnit? Memory and Politics before the 50th Anniversary of the Cultural Revolution
}

\author{
Susanne Weigelin-Schwiedrzik ${ }^{*}$ and Cui Jinke ${ }^{\dagger}$
}

\begin{abstract}
Song Binbin, the daughter of prominent CCP politician Song Renqiong, has long been accused of having played a role in the death of Bian Zhongyun which took place at the Girls' Middle School in Beijing Normal University on 5 August 1966. In January 2014, she publicly apologized for the violence that occurred at her school during the summer of 1966. However, instead of applauding her act of contrition, rebel participants of the Cultural Revolution used the opportunity to criticize the sons and daughters of high-ranking cadres and to try to overturn the 1981 official evaluation of the Cultural Revolution by promoting a positive view of that period in Chinese history. This paper analyses the background, consequences and implications of Song Binbin's apology from a political science cum memory studies perspective. It argues, against the background of a changing political landscape in the People's Republic of China, that the memory of the Cultural Revolution remains a battlefield of divergent memory groups and multiple narratives. In the memory of today, the struggles of the Cultural Revolution have still not come to an end.
\end{abstract}

Keywords: Chinese Cultural Revolution; memory; Song Binbin; Chongqing model; Bian Zhongyun

Song Binbin's 宋涁涁 apology (daoqian 道兼) for her involvement in the events that took place at the Girls' Middle School of Beijing Normal University (today known as the Experimental Middle School, Beijing shifan daxue fushu shiyan zhongxue 北京师范大学附属实验中学) in August 1966 ignited a debate among participants of the Cultural Revolution which was somewhat unexpected. Rather than commending her for having the courage to face up to her own past, many commentators were critical of her apology. This paper examines the background, consequences and implications of Song Binbin's apology from a political

\footnotetext{
* University of Vienna, Austria. Email: susanne.weigelin-schwiedrzik@univie.ac.at (corresponding author).

$\dagger$ University of Vienna, Austria.
} 
science cum memory studies perspective. It analyses both Song Binbin's attempt to put forward her narrative on the death of Bian Zhongyun 市仲䎣, the-then vice-principal of the school, during a symposium held in January 2014 organized together with classmates from 1966 and entitled "Coming to terms with the Cultural Revolution and refusing to forget" ( fansi wenge jujue yiwang 反思文 革拒绝遗忘), and the debate sparked by her apology in the Chinese media.

Our discourse analysis focuses on comparing recent narratives on the memory of the Cultural Revolution with those from 2006. Additionally, we look at the political landscape in the People's Republic of China (PRC) today and its influence on the development of the official historiography of the Cultural Revolution. Our analysis is based on documentation from the symposium published in the electronic journal, Jiyi 记忆 (Remembrance), which, since 2010, has provided a platform for the exchange of information and discussion about Bian Zhongyun's death. ${ }^{1}$ Reactions to Song's apology were published in a variety of formats, ranging from newspaper articles to blog entries. While both authors of this article have been following the debate on Song Binbin's involvement in the death of Bian Zhongyun for many years, neither has been directly involved in the recent or past developments related to this event. As non-participant observers, we rely solely on written sources for our analysis and have explicitly refrained from interviewing the discourse participants introduced below. This makes our contribution different from the many publications in Chinese and English written by authors involved in the event. ${ }^{2}$ In contrast to these publications, we focus on the political implications and see the debate surrounding Song Binbin's apology as an important battleground for the power struggle between at least two groups in the Chinese Communist Party (CCP) and in society: those who rely on social as well as economic capital accumulated prior to the Xi Jinping 习近平 administration, and those who see themselves as left behind by the politics of reform and opening.

In comparison to the debates on the Cultural Revolution held before and during the 20th anniversary in 2006, the so-called Maoist rebel faction has been extremely active in recent times and intent on trying to pose a counter-narrative to the position of "totally negating the Cultural Revolution" (quanpan fouding wenhua da geming 全盘否定文化大革命) advanced by the 1981 "Resolution on some questions concerning the history of the CCP since the founding of the People's Republic of China" (Guanyu jianguo yilai dang de ruogan lishi wenti de jueyi 关 于建国以来党的若干历史问题的决议). According to the rebel faction, Deng Xiaoping 邓小平 and Liu Shaoqi 刘少奇 are to blame for the excessive violence of 1966 and Mao's overall strategy was correct. Xi Jinping's new interpretation of

1 Jiyi is an electronic journal which has played an important role in making the memory of the Cultural Revolution "public" and in providing a platform for those who were willing to reconsider what they had done during the Cultural Revolution. The journal published several special issues on the so-called "5 August event" and documented the symposium of January 2014. It is a non-public publication but can be accessed at www.xujuneberlein.com/remembrance.idx.html outside China. See also Wu Di 2014a; 2014b.

2 See Wang, Youqin 2004; Ye 2014. 
post-1949 history, offered under the motto of "the two thirty years should not negate each other" (liang ge sanshi nian bu neng xianghu fouding 两个三十年不 能相互否定), demonstrates that the rebel faction's arguments are not totally out of line with the current orthodoxy. ${ }^{3}$

\section{What Happened on 5 August 1966?}

Song Binbin in fact first made a public apology in as early as 2010 for her role in the events in August 1966 that led to the death of Bian Zhongyun. However, her apology at that time largely went unnoticed. ${ }^{4}$ In 2014 , she declared that she had nothing to add to the version of events she gave in her 2010 statement. ${ }^{5}$ In this version, she described how the so-called work team had started mobilizing students to criticize Bian Zhongyun and others for their revisionist standpoints already in late June 1966. It was in this context that Bian was accused of being a “false Party member" (jia dangyuan 假党员), which made everybody highly agitated and angry with her. ${ }^{6}$ In addition, someone from outside the school who had a history of confrontation with Bian Zhongyun aired her grievances and attacked Bian physically. This is when several people started to beat up members of the school's leadership. In response, two teachers along with Song Binbin and her classmate Liu Jin 刘进 were asked to discuss the issue with Deng Xiaoping, whose daughters were enrolled in the Girls' Middle School of Beijing Normal University and who was to supervise the work team (gongzuozu 工作组) at this school. However, soon afterwards, the work team had to leave the school, which is why neither the leadership of the school nor anyone else had the authority to control the situation. In fact, those who had cooperated with the work team, such as Song Binbin, were regarded as “conservative” (baoshou 保守) and had lost their authority. ${ }^{7}$ According to Song:

On 5 August, those serious events took place as a consequence of violent activities in school, which eventually led to the death of Vice-principal Bian. At first, I did not know that the leadership of the school was going to be paraded through the campus; it was only later that I learned that some schoolmates from the first grade of the upper division had started this. That afternoon, Liu Jin and I sat together with some other classmates in the office occupied by the work team on the second floor of the East Building to discuss what to do next. Suddenly, some students from the lower division ran in to tell us that students were beating up people on the sports ground. Liu Jin, myself and some other classmates who had been on the students' representatives committee and in the core group ran to the sports ground and saw how Vice-principal Bian and five others from the school's leadership were forced to present themselves ... We tried to convince them [i.e. the fellow students] that they should not beat up people, but they ... could

3 See Zhu 2013.

4 Song 2012.

5 Song 2014.

6 This expression refers to a Party member who was introduced to the Party by someone who later turned out to be a traitor. During the Cultural Revolution, many people who joined the Party during the Anti-Japanese War were accused of being "false party members."

7 Song 2014. For an in-depth analysis of the situation in Beijing, see Walder 2009; for a recent overall assessment of the Cultural Revolution, see Walder 2015, especially 215-19 for the situation in Beijing's high schools. For an analysis by a PRC author, see Xu, Youyu 1999. 
not see any wrong in making them march in the streets ... We made the people leave the scene and went back to the second floor of the East Building. Later on, schoolmates from lower grades came and told us that the beatings were still going on behind the sports ground. Liu Jin and I went to have a look and saw many schoolmates gathering behind the sports ground with members of the school's leadership forced to carry soil in baskets which were so full and heavy that they could not move. They were beaten and scolded for that. Liu Jin and I advised the schoolmates who were supervising the school's leadership that to work means to work and cannot be accompanied by beating up people. With the baskets as big as they were, they could not be blamed for not being able to carry them. As we saw that they did not object, we left the scene ... On the evening of 5 August, I heard the rumour that Vice-principal Bian was lying on the sports ground just about to die. Liu Jin and I ran immediately to the sports ground. Teacher Li Songwen was also there. Liu Jin asked a worker on campus to open the backdoor, and we [took] Principal Bian into the Postal Hospital. ${ }^{8}$

\section{Whose Story Is This?}

Bian Zhongyun's death, along with the involvement of the students from the Girls' Middle School of Beijing Normal University, has been a topic of internal review and public discussion since the end of the 1990s. Liu Jin, one of the leading student cadres in the school in 1966, reports that she attended the memorial service for Bian Zhongyun in 1978 and that, in the early 1990s, she went back to her former middle school to look for archival materials. She talked to her former teachers but did not find the time to write things down before she went into retirement. ${ }^{9}$ Feng Jinglan 冯敬兰, one of the organizers of the aforementioned symposium, claims that she had begun to work on this issue in 1996, and in 2000 wrote down her recollections of the incident. ${ }^{10}$ Ye Weili 叶维丽 reports that she began her research into the death of Bian Zhongyun in 2000/2001. ${ }^{11}$ After meeting up with Liu Jin in 2002, they both decided to commit time and energy to the project and began to get in touch with others who may have witnessed Bian's death.

Some people started even earlier, among them another former vice-principal of the school, Hu Zhitao 胡志涛, who wrote about the incident in quite some detail in a text entitled "In remembrance of 5 August," which was published in 1986. ${ }^{12}$ Wang Youqin 王友琴, who also happened to have been a student at this particular school, started researching Bian's death in the 1990s and wrote at great length about it in her book, Victims of the Cultural Revolution, published in 2004.13 Carma Hinton and Geremie Barmé made a documentary on Red Guard memories of the Cultural Revolution, with many hours of film footage in which both Ye Weili and Song Binbin appear - without once referring to Bian's death, however. ${ }^{14}$

8 Song 2012, 8. All extracts and quotations used in the article have been translated into English by the authors.

9 Liu 2012.

10 Feng 1997; 2014. Feng Jinglan reports that Bian Zhongyun was officially rehabilitated in the spring of 1970.

11 Ye 2014.

$12 \mathrm{Hu}$ 1986. For more on $\mathrm{Hu}$ Zhitao, see Ye and Ma 2005.

13 Wang, Youqin 2004.

14 For more details on the film, see http://www.pri.org/stories/2014-01-24/chinese-filmmaker-points-hiscamera-darkest-moments-communist-party-history. Accessed 22 June 2016. For a Chinese version with optional German subtitles, see $\mathrm{Hu}$, Jie 2009. 
In 2006, $\mathrm{Hu}$ Jie 胡杰 made a 70-minute documentary on Bian with the title, Though I Am Gone, with Bian's husband, Wang Jingyao 王晶圭, as his main informant. ${ }^{15}$

From these publications and documentaries, it can be seen that the former schoolmates, all belonging to the so-called lao san jie 老三届 generation, were "comrades in arms" at the time of the Cultural Revolution. ${ }^{16}$ They had lost touch after the events of 1966, it seems, and re-established their relationships in the early to mid-1990s. It took them nearly 30 years to recover their friendships and form a "carrier group" of Cultural Revolution memory. ${ }^{17}$ Carrier groups are formed from among "insiders" sharing similar, and in this case traumatic, experiences as victims or perpetrators. They exchange memories among themselves and refrain from communicating with "outsiders" while developing their own narrative of the past. Soldiers share their memories of war in carrier groups, and participants of the Cultural Revolution preserve their fragmented memory by communicating with their friends from that time. They claim that only people who experienced the traumatic events with them can understand what happened. Because this form of coming to terms with the past is not public, outside observers gain the impression that the Cultural Revolution is forgotten. Instead, different carrier groups develop their own respective narratives, which often differ sharply from the official version given in the 1981 Party Resolution. ${ }^{18}$

The participants of the 2014 symposium have formed a carrier group of Cultural Revolution memory and have also defined the rules of inclusion and exclusion. In their recent statements, they all give their affiliations with different grades of the upper division of the middle school and explain their family background as belonging to the upper, but not the highest, level of central cadre families in Beijing. This shows that social background and belonging to the same grade in school are two important criteria for membership in this carrier group. That is why Wang Youqin does not belong to the group. She does not fulfil the "objective criteria," as she is younger and of a different family background (she comes from a family of teachers). In addition, the carrier group does not allow for any member to be called perpetrator; instead, they explicitly define themselves as more or less "responsible actors." However, Wang Youqin does not accept this definition and instead has accused Song Binbin of having actively participated in the beating which eventually led to the death of Bian Zhongyun. ${ }^{19}$ Since Song Binbin's 2012 apology, many people who used to believe Wang Youqin's story are now convinced by Song Binbin's narrative;20 however,

15 There are several versions of the film available with English, German and French subtitles. For the Chinese version, see www.youtube.com/watch?v=gXWzAsHE-Pg. Accessed 16 June 2016.

16 The expression lao san jie refers to those upper-division middle school students who graduated during the years 1966, 1967 and 1968.

17 Weigelin-Schwiedrzik 2008.

18 See Weigelin-Schwiedrzik 2006; 2008; Gao 2008; Yang 2007.

19 Jin 2014.

20 Xu, Youyu 2014. 
Wang Youqin still refuses to accept Song Binbin's version. ${ }^{21}$ This shows that Wang is not part of the consensus formed by the carrier group and therefore cannot join them.

Bian Zhongyun's husband, Wang Jingyao, is also not a member of the carrier group. One of the reasons why this event has garnered so much attention is because Wang, as he explains in Hu Jie's film, ${ }^{22}$ refused to forget and began to gather as much evidence as he could as soon as he was informed of his wife's death on the evening of 5 August 1966. Although some members of the carrier group have had contact with the now 94-year-old Wang Jingyao, he and his family were not present at the official apology ceremony in front of a statue of Bian Zhongyun erected at the Experimental Middle School in Beijing. ${ }^{23}$ How was this possible? Wang has, to the best of our knowledge, never claimed that Song Binbin actively participated in what he terms the murder of his wife. Instead, he tried to take another person to court, someone who he believes mobilized the students against his wife, but his request for a trial was turned down in the 1980s on account of the time elapsed. So, how could it be that the apology was not addressed to him, as one might expect? This is because Wang Jingyao does not comply with the rules of the carrier group, which insist that no member of the carrier group can be accused of being the perpetrator and no one must disclose who the perpetrator was. Wang Jingyao, on the other hand, insists that the perpetrator should reveal herself or else be exposed by others. As this demand cannot be complied with, he cannot, and maybe does not even want to, be included in the group. Moreover, Wang Jingyao insists that Mao Zedong should be squarely condemned for his "mistakes" which made possible the outburst of violence in the second half of 1966. Song Binbin's apology at no point referred to Mao's role in the events, and so Wang refuses to accept her explanation and is unconvinced by the narrative accepted by those who participated in the symposium. ${ }^{24}$

There are quite a number of former schoolmates from 1966 who do not form part of the carrier group. Most prominent among them are the daughters of Liu Shaoqi and Deng Xiaoping. Both attended the school at the time and have on occasion been publicly accused of having taken an active part in the beating of Bian Zhongyun. ${ }^{25}$ The sister of Bo Xilai 薄熙来 also belongs to this group. ${ }^{26}$ The simplest explanation for this is their family background: they all come from families whose political and social position was even higher than those in the carrier group. However, the reason why they stick to their code of silence is more complicated. It relates to an aspect of the Cultural Revolution which has so far never been publicly addressed in the PRC: the participation of the

21 Jin 2014.

22 See Fn. 15.

23 Lundunke 2014

24 Wang, Jingyao 2014.

25 Lundunke 2014.

26 Wang, Youqin 2014. 
sons and daughters of the leadership of the CCP back in 1966, and their relationship to their parents at that time. Although it is clear that the so-called Old Red Guards (lao hong weibing 老红卫兵) were heavily involved, no one has so far taken responsibility for the outburst of violence during the initial phase of the Cultural Revolution. Instead, the 1981 Party Resolution refrains from assessing this period and from condemning the Old Red Guards. ${ }^{27}$ Recently published materials show that in as early as 1979, the involvement of this group was under investigation when Peng Xiaomeng 彭小蒙, a former leading Red Guard at the middle school affiliated to Peking University, allegedly wrote a letter to $\mathrm{Hu}$ Yaobang 胡耀邦 concerning this issue. ${ }^{28} \mathrm{Hu}$ Yaobang responded by saying that many young people had committed mistakes during their time as a Red Guard, but most of them lacked experience and were used or misled. That is why they should not be condemned but instead be helped to overcome their mistakes. ${ }^{29}$ The silence of the 1981 Resolution on this question is in line with $\mathrm{Hu}$ Yaobang's response, but failed to calm the fears of the former Old Red Guards. In 1984, Red Guard activism was again under review, with many Old Red Guards eager to draw a clear line between themselves and the so-called rebels (zaofanpai 造反派). In another letter, this time to Chen Yun 陈云, the group underlined the necessity to abstain from persecuting Old Red Guards who had committed mistakes; instead, their positive participation in the early phase of the Cultural Revolution should be acknowledged and they should be mobilized to participate in the continuing struggle against the "three kinds of people." 30

Since the early 2000s, the death of Bian Zhongyun has grown into an issue of emblematic function for the assessment of Red Guard activism in 1966. That is why, after more than 20 years of research and discussion, we still do not know for sure who killed Bian Zhongyun. Song Binbin and all other members of the carrier group see themselves as non-participants in the beating; however, they are also not prepared to reveal the names of those who did take part, as they are all part of a larger carrier group consisting of those Old Red Guards who regard themselves as being "used or misled" during the early phase of the Cultural Revolution. Because they do not want to run the risk of being expelled from this carrier group, they stick to the rules - even if this means that they themselves remain under suspicion.

\section{In Search of Truth and Reconciliation}

The carrier group from the Girls' Middle School set as its major task the search for the truth about the death of Bian Zhongyun. Liu Jin admits that she was the

27 Weigelin-Schwiedrzik 2006.

$28 \mathrm{Xu}$, Xinhua 2011, 41.

29 Ibid., 42.

30 Mi 2013, 168-69. The "three kinds of people" refers to those who actively supported Lin Biao and the Gang of Four, people who were strongly influenced by their political ideas, and people who had participated in riots. The expression was first used in a speech presented by Chen Yun in 1982. In this speech, he clarified that members of the "rebel faction" could not be elected to cadre positions. See zh. wikipedia. org/wiki/清理三种人. Accessed 16 June 2016. 
first to write a big character poster (dazibao 大字报) criticizing the so-called work team. Like many others at the time, she criticized the work team for being too rigorous in exerting its leadership over the movement and demanded instead that students should be encouraged to liberate themselves. This big character poster, as Liu Jin states today, was responsible for creating an uncontrollable situation on campus and one of the reasons for the outburst of violence. She has, in fact, been doing research on the 5 August event for a long time, undergoing several rounds of inspection related to the case and writing up documentation for the school's archives. Her contribution is remarkable because of the rigorous attitude she has taken with regards to herself and her contribution to the events, and her convincing attempt to uncover the reasons for her behaviour back in 1966. ${ }^{31}$

In contrast, Ye Weili presents herself as a researcher: "I am a historian as well as one of the students at the Girls' Middle School back then. This means that I cannot stand above or outside [of the events] while trying to find an answer to the question 'whose responsibility' [has to be taken into account] in the context of Principal Bian's death ... but that I have to put myself right into this ... and shoulder the most horrible collective shame that the Girls' Middle School has accumulated in its history." 32 While Liu Jin mostly looks at her deep-seated, internal motivations, Ye Weili focuses on external pressures and comes to the overall conclusion that the violence of those days was very much owing to the total loss of control of the authorities at all levels of the political system.

Li Hongyun 李红云 represents yet another approach to the death of Bian Zhongyun. In Jiyi, she explains that she only became aware of the controversy when the school was commemorating its 90th anniversary in 2007 and some people suggested erecting a statue for Bian Zhongyun on campus. ${ }^{33}$ "I am in law, and clarifying the truth about things is the first step before you can make any assessment in a case. As a graduate of the Girls' Middle School and belonging to the generation which personally experienced the Cultural Revolution, I feel that I have a duty to clarify this event." ${ }^{34} \mathrm{Li}$ Hongyun explicitly refers to the situation in South Africa, underlining that the ultimate goal of coming to terms with the past is reconciliation: "If countries like South Africa, Sierra Leone and Rwanda can achieve reconciliation and mercy in their attitude towards the past, why should a

31 Liu 2014.

32 Ye 2014, 13-14.

33 For more details on the anniversary celebrations, see Jian, Song and Zhou 2015. Song Binbin was one of the "eminent graduates" from this school selected for special mention during the school's 90th anniversary celebrations. The photograph used in the commemoration booklet accompanying the celebration shows her participating in the 18 August 1966 parade on Tian'anmen Square when she attached the Red Guard armband to the jacket of Mao Zedong. This implies that Song Binbin's eminence was owing to her participation in the Cultural Revolution. For more about Wang Jingyao's protest at the selection of Song Binbin as one of the "eminent graduates" from the school, see www.360doc.com/ content/07/1226/23/16239_927133.shtml. Accessed 16 June 2016. 
country with thousands of years of civilization and tradition like China not do the same?"35

Song Binbin presents herself as both a leader of the students at the Girls' Middle school and a victim of the political situation during the Cultural Revolution. She begins her contribution to the 2014 symposium by stating: "Since about 40 years ago there have been two Song Binbins: one Song Binbin who from the very beginning argued against armed struggle, violence and 'the theory of descent,' a Song Binbin who can take responsibility for whatever she did. The other Song Binbin is a creation under the name of 'Song Yaowu' 宋 要武 [Song who wants violence], she was fabricated during the Cultural Revolution and the 1990s."36 In Carma Hinton's film, Song is more forthcoming as she explains that it was Mao Zedong who took her identity away from her by bestowing a new name on her. This name was then used in order to mobilize young people in Mao's struggle against Deng Xiaoping and Liu Shaoqi, as she contends, without her consent. All of this happened because, as Liu Jin states, Song Binbin was chosen by Liu Jin to represent the Girls' Middle School during the mass meeting on Tian'anmen Square on 18 August $1966 .{ }^{37}$ It was during this meeting that Song Binbin was given the opportunity to place a Red Guard armband on Mao's jacket sleeve: “that Chairman Mao wore the armband of the Red Guards, together with the phrase 'how about some violence' (yao wu ma 要武嘛), ignited some kind of madness to protect the great leader of the country ... Together with everyone and every family I want to denounce all violence which took place because of 'Song Yaowu' and other reasons." 38 But, her role as a victim of the Cultural Revolution has yet another side to it. Later on in her presentation, she talks about her father being labelled as a "capitalist roader" in 1967, her mother and brother being paraded in the streets of Shenyang, and how she herself was kept in isolation. ${ }^{39}$ This experience was very typical for Red Guards with her family background. It is why her self-perception as a victim of the Cultural Revolution dominates the narrative of her apology and makes it less convincing.

Looking at the documents published by Jiyi, one can gain a good understanding of the enormous efforts the members of the carrier group have made since the 1990s in coming to terms with the death of Bian Zhongyun. Their courage to confront this event publicly is admirable. Alas, while all of them concentrated on defining their own role in the event and unanimously came to the conclusion that none among them was directly involved in the beating, they have not had the courage to present the names of those who were directly involved. This, of course,

35 Ibid., 23. The public's interest in the reconciliation process in South Africa is reflected by the recent translations and publication of books on the issue by Albie Sachs and Desmond Tutu. See Sachs 2014 and Tutu 2014.

36 Song 2014, 31.

37 Liu 2012, 17.

38 Song 2014, 32.

39 Ibid., 33-35. 
leaves the victims as well as the interested public unsatisfied and doubtful, as it is clear that there is something to this case everybody knows but nobody dares to address.

This is exactly the reason why Bian's husband, Wang Jingyao, condemns what he deems "a false apology": "As long as the full truth about the ' 5 August event' is not out there, I will definitely not accept the false apology given by Red Guards from the Girls' School of Beijing Normal University." 40 However, the reason why this truth has not fully come out is not because the perpetrator is among them; instead, we would argue that it is precisely because no member of the carrier group was directly involved that they can do the research and go public. Only with the carrier group remaining as active and diligent as they are can the group of direct participants stay silent.

The question arises why Song Binbin and her classmates decided to present their public apology at this particular moment. Some of the reasons seem quite obvious. All of those who were at the centre of events have retired. Both psychologically and from the point of view of practicability, it is easier to confront one's own past in a situation where one is able to choose one's own social contacts. The risk of being met with mistrust, criticism or unfriendly behaviour at work or in one's professional life is no longer there. Other reasons are less obvious and relate to the political climate in the PRC. As economic growth slows down, the initiators of the opening and reform policy are afraid of losing momentum while a counter-narrative is in the making which is critical of the reform and of the role the reformers played during the second half of 1966. The offspring of the reformers, such as Song Binbin, try to be proactive in presenting their version of events during the early phase of the Cultural Revolution.

\section{A Counter-narrative in the Making}

Until recently, Old Red Guards were regarded as having committed mistakes, which, however, did not prevent them from going on to forge a political career in China. In contrast, those who were said to have belonged to the so-called "three kinds of people" were expelled from the system during the Cultural Revolution and hardly ever found their way back. These people now recognize that Song Binbin has provided them with the opportunity to use the obvious flaws in her apology to present their own version of the Cultural Revolution.

This seems to be the reason why on 13 January 2014, when the debate on Song Binbin's apology was first ignited, the Internet Information Bureau of the State Council of the PRC (guowuyuan hulianwang xinxi bangongshi 国务院互联网信息 办公室) issued a directive saying: "Because the mood on the net is complicated, all websites should hold reports on the apology of Song Renqiong's 宋任穷 daughter Song Binbin at a low temperature, [which implies] that reports on 
this issue should be erased from the front page and connecting links on this issue should not be presented." 41 While this directive was meant to bring the discussion to a sudden end, Nanfang zhoumo 南方周末 (Southern Weekly) continued to publish articles on the issue. The editor-in-chief consequently had to write a report and accept that the newspaper was no longer allowed to publish articles on Song Binbin's apology. ${ }^{42}$ However, both the Chinese and non-Chinese language press outside of the PRC continued to discuss the issue, and blog entries were posted in the internet.

The verdict on the Old Red Guards can be construed from the absence of any verdict on their activism during the early phase of the Cultural Revolution in the 1981 Party Resolution. ${ }^{43}$ In contrast to what one might assume from reading blog entries posted by the Maoist faction, there is also no straightforward verdict on the rebel factions included in the 1981 Resolution. One of the Resolution's main aims was to prevent the continuation of factional struggles and so it omitted to include a verdict on either the Old Red Guards or the rebels. ${ }^{44}$ However, we can see from the reactions to Song Binbin's apology that the rebels from among the "three kinds of people" are now attempting to overturn what they perceive as the implicit verdict of the Resolution. In one blog entry by Li Yang 黎阳, a commentator well known for his affiliation with the Maoist faction, Li criticizes Song Binbin's apology for providing everybody who did similar things during the Cultural Revolution with the opportunity to absolve themselves of their responsibility by simply apologizing. This ritual implies the possibility that people not only ask for apologies by other individuals but want, as Xu Youyu 徐友渔 supposedly claims, the state to take on collective responsibility and forward an apology to every victim of the Cultural Revolution. Li Yang contends that under these conditions, it could be argued that the state is "a criminal organization." Song Binbin's apology - according to Li Yang - might help her personally and as an individual, but it threatens the stability of the state and is therefore dangerous. ${ }^{45}$

Another entry in a blog explains:

Even if Bian Zhongyun was really harmed by extreme brutality, this should not be counted as something related to Mao Zedong. This is because Mao launched the Cultural Revolution with the aim of mobilizing bottom-up against bureaucrats and the capitalist roaders inside the Party. Who would have guessed that some people from the upper levels would use this opportunity to

41 See http://chinadigitaltimes.net/2014/01/red-guard-apologies-role-teachers-death/. Accessed 4 June 2015. According to its official website, China Digital Times (Zhongguo shuzi shidai) is based in Berkeley, CA, and is an independent, bilingual media organization that publishes uncensored news and online voices from China. The Chinese version of CDT has a section called the "Truth department directions" (zhenlibu zhiling), where one can see the censorship instructions issued by all kinds of censorship departments in China. For the Chinese version, see http://chinadigitaltimes.net/chinese/category/有关部门/真理部指 令/. Accessed 15 June 2016.

42 Nanzhou gengzheng 2014.

43 "Guanyu jianguo yilai dang de ruogan lishi wenti de jueyi" (Resolution on some questions concerning the history of the CCP since the founding of the People's Republic of China), Renmin ribao, 1 July 1981, $1-8$.

44 Weigelin-Schwiedrzik 2006.

45 Li, Yang 2014. 
change the mode of struggle into a top-down mobilization under the leadership of the bureaucrats? They changed the object of the struggle from the bureaucrats to the students, the teachers and workers at the first front of production ... and thus destroyed Mao's strategic orientation for the Cultural Revolution. ${ }^{46}$

According to this narrative, what happened to Bian was not part of Mao's strategic plan but rather belongs to an anti-Cultural Revolution strategy invented by those Mao wanted to expel.

In January 2014, another blogger comes to the conclusion that:

It is now time to reverse the verdict on the Cultural Revolution because only a positive assessment of the Cultural Revolution can be the basis of a positive assessment of Mao and the 30 years under his leadership. I see that some of those who offer apologies for the Cultural Revolution have ulterior motives. One of their aims is to stick to the total negation of the Cultural Revolution. Thus, the parent generation of Chen Xiaolu 陈小鲁 47 and Song Binbin who made enormous contributions to the founding of the People's Republic can forever be regarded as victims and the embodiment of the truth, their parents will forever have been correct, and Mao Zedong will forever have been mistaken. The masses of the people will never again have the opportunity to challenge the bureaucratic class which acts against the principles of communism, while those bureaucrats who misuse their power for their own interest or who have degenerated can sit back and relax in peace and happiness. ${ }^{48}$

The negation of the Cultural Revolution, driven by the 1981 Resolution, implies total disempowerment for the masses.

In yet another blog entry, the author argues against the 1981 Party Resolution. According to this author's interpretation, the Red Guards were ordered by their parents to destroy the Cultural Revolution before it ever got started. They acted on behalf of the class of leading families who wanted chaos to break out in the hope that this would prevent the Cultural Revolution from fanning out across the whole country. However, once the Cultural Revolution group brought this to a halt, the offspring of the leading bureaucrats had to break publicly from their parents. ${ }^{49}$ From a family point of view, the Old Red Guards see themselves as victims of the Cultural Revolution, yet from an individual point of view, they see themselves as victims of Mao Zedong. The Maoist bloggers, however, argue that they were persecuted by "the bureaucrats." When the movement to clarify the ranks of the "three kinds of people" was launched, those among the rebels who had taken over leading positions at the lower levels of the state were interrogated, degraded and sometimes even sent to prison. After the Cultural Revolution, many of them were never given the chance to take up important political or bureaucratic positions. Both Old Red Guards and rebels, while commonly regarded as perpetrators, insist on being victims.

This new discourse strategy is radically different to the situation in and around 2006. At that time, the debate excluded those victims who were maltreated,

46 Shidai Jianbing 2014.

47 Chen Xiaolu is the son of Marshall Chen Yi. He first offered his apologies to his former teachers in Beijing No. 8 Middle School in a blog entry of alumni from his school before he went public during a visit to the school on 7 October 2013. See Huang 2013.

48 Fu Niu Shi 2014.

49 Wenhua Hong Weibing 2014. 
murdered or driven to suicide, and victim status was seen as something negative. ${ }^{50}$ Now, ten years later, both the Old Red Guards and the Maoist rebels seem to regard their status as victims of the Cultural Revolution as social capital which they can use in their struggle for satisfaction, impact and power. However, in a continuation of the tone of the 1981 Resolution, they do not express any empathy for the dead victims.

The Maoist rebels see the Cultural Revolution as the antithesis of all that is happening in China today: workers and peasants were "the masters of the country" (dang jia zuo zhu 当家做主) instead of being threatened by unemployment and the loss of their land. This argument is often put forward by members of the Maoist faction who were too young to have actively participated in the Cultural Revolution; they were primary school children at the time and often not aware of the details of what happened back then. In 2005/2006, they criticized the reform and opening up policy by juxtaposing the situation in China today with life during the Cultural Revolution. ${ }^{51}$ The Maoist faction among the rebels seems to have aligned with this younger group of Cultural Revolution participants and, as a result, they have formed a much more prominent force in the discourse. ${ }^{52}$

\section{The Changing Orthodoxy of the CCP Historiography}

The 1981 Resolution constructed "universal complicity" with the aim of pacifying the tension between different factions, the perpetrators and victims, the winners and losers, of the Cultural Revolution. However, the notion of "universal complicity" was not accepted by those who had experienced the Cultural Revolution and, as a result, the Resolution was contested as soon as it was passed. Another reason why it failed to establish itself as the dominant text in the discourse on the Cultural Revolution is because for some the Resolution was not pronounced enough in “negating” (fouding 否定) the Cultural Revolution; for others it went too far. As a result, the CCP has tried to block public discussion of the Cultural Revolution, albeit with little success. ${ }^{53}$

The new slogan promoted by Xi Jinping about the "two 30 years" is meant to balance the relationship between the "first 30 years" and the last 30 years of reform and opening. ${ }^{54}$ As such, Party historiography can find positive aspects of

50 Weigelin-Schwiedrzik 2008.

51 Gao 2008 analyses the web communications on the Cultural Revolution around the 2006 anniversary and finds that the "younger" generation nostalgically referred to the Cultural Revolution as a time of justice and equity, in contrast to the aggravating social injustice they observed in the China of reform and opening. See also Yang 2007. Both Gao and Yang argue that the internet can serve as a platform to voice alternative views on the Cultural Revolution despite the official ban on publicly discussing the issue.

52 We would like to thank Yin Hongbiao from the School of International Studies, Peking University, for drawing our attention to this aspect of Red Guard memory.

53 Weigelin-Schwiedrzik 2006.

54 The slogan of the "two 30 years" first appeared in 2009 in an article published in the Renmin ribao on 17 August. The article explained how the first 30 years following the founding of the PRC could not be 
the Cultural Revolution just as it can describe negative aspects of the period since 1978. The overall aim is to come to a positive assessment of 100 years of CCP history in 2021 as well as 100 years of PRC history in 2049. So far, Party historiography has basically underlined Mao's positive role in CCP history; however, as a consequence of Mao's antagonists taking control at the end of the Cultural Revolution, Party historiography also has to criticize Mao in order to make the policy of reform and opening plausible in the context of CCP history. The more arguments began to circulate stressing that the consequence of reform and opening was exactly what Mao had warned against when he talked about "restoration," the more the policy of reform and opening had to be supported by criticism of Mao Zedong. ${ }^{55}$ The recent discussions on the Cultural Revolution demonstrate that the Maoist faction among the rebels wants to push Party historiography into a more positive assessment of Mao while reinforcing their fight against social injustice, bureaucracy and corruption.

The question arises why Party historiography needs to respond to the demands of the Maoist faction. As is well documented, Xi Jinping was elected as the leader of the Chinese Communist Party after one of his most important rivals, Bo Xilai, was sentenced to life in prison. Although everybody refers to Bo Xilai's policies in Chongqing as being nostalgic of Maoist times, very little analysis has so far been offered of how these policies were connected to the Cultural Revolution. That there is more to Bo Xilai's relationship with the Cultural Revolution was first pronounced by the-then premier Wen Jiabao 温家宝 at a press conference in 2012 following the meetings of the National People's Congress and the People's Consultative Congress. ${ }^{56}$ But, as Xu Youyu points out, already before then there were rumours afloat that the so-called "Chongqing model" (Chongqing moshi 重庆模式) owed much to the Cultural Revolution. ${ }^{57}$ Indeed, it can be argued that the Chongqing model shared much with the Cultural Revolution in its ability to mobilize people. As the channels of participation have not changed since the end of the Cultural Revolution, Xu Youyu argues, it is perhaps inevitable that people remember the model of the Cultural Revolution as a means of instigating change in instances of mass dissatisfaction. ${ }^{58}$ Interestingly, this is true both for national leaders such as Wen Jiabao who were obviously highly agitated by the thought of a reoccurrence of the Cultural

footnote continued

used to negate the last 30 years of the PRC, and vice versa. See Wang, Tinglian 2009. In 2013, Xi Jinping reiterated this idea when he gave a speech to the newly elected and alternate members of the CCPCC. See Mei 2013.

55 Wang Tinglian argues that "the two 30 years" should be interpreted in a balanced way also in order to arrive at a proper assessment of Mao Zedong. Wang, Tinglian 2009.

$56 \mathrm{Xu}$, Youyu 2014, 3.

57 Ibid.

58 Ibid., 4-5. 
Revolution, and for the led masses who followed Bo Xilai for a certain period of time. $\mathrm{Xu}$ writes:

The Chongqing model awakens our attention to [the fact] that the Cultural Revolution is not a nightmare which we all have forgotten long ago. It is a real danger right in front of our eyes. It is not the catastrophe propagated as set in stone, but an event which quite a number of people regard as a big festival and the political instrument [with which] to achieve equity in social reality ... The reality we have to confront is: the Cultural Revolution was supported by millions of people. They participated in this political movement with sincerity and enthusiasm. If we want to understand why there are so many today who call for a cultural revolution, we have to understand what reason they had back then to throw themselves into the Cultural Revolution. ${ }^{59}$

If $\mathrm{Xu}$ Youyu's analysis is right, the present leadership of the CCP has to confront a dilemma: Bo Xilai and the Cultural Revolution enjoyed considerable support in China, but the current leadership expelled Bo Xilai from the elite ranks in order to install Xi Jinping. The leadership cannot allow for any signs of open support for Bo Xilai, which is why they feel compelled to give space to more and more positive memories of the Cultural Revolution instead. It is also why we can now observe that it is more difficult in China to offer apologies for violence in the early stage of the Cultural Revolution than it is to overturn the official opinion of the Cultural Revolution as given by the 1981 Resolution. As for Party historiography, the need to accommodate the arguments from those who demand a positive assessment of the Cultural Revolution is, under these conditions, more urgent than the need to respond to those intellectuals and their families who were murdered or seriously injured during those turbulent times.

\section{Conclusion}

According to the analysis presented above, the memory of the Cultural Revolution has again turned into a battlefield of conflicting carrier groups. While members of the Old Red Guards tried to avoid losing momentum by proactively proffering their apologies, the Maoist faction among the rebels identified a window of opportunity through which they could attempt to reverse the CCP verdict on the Cultural Revolution and overcome the negative image they have borne for so many years.

The discourse on Song Binbin's apology shows that perceptions of social justice, of what is politically right and wrong, and of dreams for the future are still shaped by ideas propagated during Maoist times, especially during the Cultural Revolution. The more the present situation is regarded as unsatisfactory, the more the Cultural Revolution emerges from the discourse as a possible and feasible alternative. Paradoxically, this is true despite the fact that all discourse participants claim to be victims. The factional divide responsible for much of the violence during the Cultural Revolution still exists to the degree that the participants are not yet ready for reconciliation. The victims have little empathy for 
each other and are still competing with each other for recognition and power. In this sense, the Cultural Revolution is still going on.

The attempts of the CCP to ban public discussions of the Cultural Revolution have had a limited effect. Although it is still impossible to dispute the 1981 Resolution openly, internet blogs are used to create a counter-narrative, which is much more pronounced than ten years ago in laying the blame for the violence that occurred in 1966 at the feet of those responsible for the policy of reform and opening after 1978. Against the background of growing criticism of the social injustice in China and the slowing down of economic growth, the Cultural Revolution emerges as an alternative to a market economy. At the same time, those who were targeted as "the objects" of criticism back then are now made responsible for the emerging social dissatisfaction. In order to avoid being downgraded again, Song Binbin and other Red Guards have to erase the stain seeping from rumours that they were actively involved in acts of murder. They either deny direct involvement, as Song Binbin did, or they claim moral superiority by openly admitting their involvement, as Chen Xiaolu did. ${ }^{60}$ In both cases, they did not receive the expected response. Song Binbin's apology represents an abortive attempt at preserving the positive image of leading cadres and their families based on their victimhood during the Cultural Revolution.

\title{
Biographical notes
}

Susanne Weigelin-Schwiedrzik is professor of Sinology at the department for East Asian studies at the University of Vienna, Austria.

Cui Jinke is a doctoral student of Sinology at the University of Vienna, Austria.

\begin{abstract}
摘要: 1966 年 8 月 5 日, 北京师范大学附属女子中学的市仲耘校长被学生打 死在校园里。中国共产党的高级领导人宋任穷的女儿宋涁涁, 很长一段时 间以来都被指责参与了这一事件。2014 年 1月, 她公开为 1966 年夏天发 生在自己学校的暴力事件道歉。但是, 她的道慊并没有获得掌声, 而是受 到了一系列批评。部分当时属于造反派的文革参与者们利用这个机会来批 判高级干部子女, 并借此来否定中国共产党 1981 年的决议以及传播对于文 化革命的积极评价。本文以政治学与记忆研究的视角分析了宋涁涁道兼事 件的背景、后果和影响。以中国的政治图景最近所发生了各种变化为背景, 本文认为，对于文化革命的记忆还是分散性的记忆团体和多样性叙事的战 场。今天的记忆是文革派性斗争的延续.
\end{abstract}

关键词: 文化革命; 记忆; 宋涁涁; 重庆模式; 市仲耘

60 See Fn. 48. 


\section{References}

Feng, Jinglan. 1997. "Jiyi de chuangba" (The scar of the memory). In Feng Jinglan, Ni daodi yao shenme (What Do You Really Want). Beijing: Zhongguo guoji guangbo chubanshe, 123-128.

Feng, Jinglan. 2014. "Xiaozhang shi zenme si de? Yuan Beijing shida nü fuzhong wenge chuqi 'ba wu shijian' zongshu" (How did the principal die? A summary of the "5 August event" at the girls' middle school attached to Beijing Normal University). Jiyi 106(15 January), 8-11, www.xujuneberlein. com/Rem106.pdf. Accessed 4 June 2015.

Fu Niu Shi. 2014. "Wenge daoqian beihou de yiyun" (The hidden meaning behind the Cultural Revolution apologies), http://www.yzxwk.com/Article/zatan/2014/01/313051.html. Accessed 4 June 2015.

Gao, Mobo. 2008. The Battle for China's Past: Mao and the Cultural Revolution. Ann Arbor, MI: Pluto Press.

Hu, Jie. 2009. ...nicht der Rede wert. Die Ermordung der Lehrerin Bian Zhongyun am Beginn der Kulturrevolution. Neckargemünd, Vienna: Edition Mnemosyne.

Hu, Zhitao. 1986. “'Ba wu' ji” (In remembrance of "5 August”), 21 ccom.net, 4 August, http://www. 21ccom.net/articles/lsjd/lsjj/article_20140804110518.html. Accessed 4 June 2015.

Huang, Cary. 2013. "Chen Xiaolu apologizes for torture of teachers at Beijing alma mater," South China Morning Post, 16 October, http://www.scmp.com/news/china/article/1332588/ chen-xiaolu-apologises-torture-teachers-beijing-alma-mater. Accessed 4 June 2015.

Jian, Guo, Yongyi Song and Yuan Zhou. 2015. Historical Dictionary of the Chinese Cultural Revolution. Lanham, MD: Rowman \& Littlefield.

Jin, Zhong. 2014. "Fangwen wenge yanjiuzhe Wang Youqin" (Interview with Cultural Revolution researcher, Wang Youqin), open.com.hk, 3 February, http://www.open.com.hk/content.php?id= 1701\#.V04ck5F95b4. Accessed 22 June 2016.

Li, Hongyun. 2014. "Wo dui 'ba wu shijian' de yanjiu" (My research on the "5 August event"). Jiyi 106(15 January), 19-23, http://www.xujuneberlein.com/Rem106.pdf. Accessed 4 June 2015.

Li, Yang. 2014. "Song Binbin daoqian shi dahao shi”" (How wonderful that Song Binbin has apologized), Huayue luntan, 14 January, http://szhgh.com/Article/opinion/xuezhe/2014-01-14/42572. html. Accessed 4 June 2015.

Liu, Jin. 2012. "Miandui lishi de zeren - Liu Jin fangtanlu" (Confronting the responsibility for history - an interview with Liu Jin). Jiyi 80(31 January), 16-28, www.xujuneberlein.com/Rem80.pdf. Accessed 4 June 2015.

Liu, Jin. 2014. "Ba wu fansi” (Coming to terms with 5 August). Jiyi 106(15 January), 24-30, http:// www.xujuneberlein.com/Rem106.pdf. Accessed 4 June 2015.

Lundunke. 2014. "Shengyuan 93 sui de Wang Jingyao - jianping Song Binbin de xuwei daoqian" (In support of 93-year-old Wang Jingyao - evaluating the false apology of Song Binbin), blog. wenxuecity. com, 5 February, http://blog.wenxuecity.com/myblog/61670/201402/3595.html. Accessed 22 June 2016.

Mei, Hong. 2013. "Ruhe zhengque pingjia gaige kaifang qianhou de sanshi nian" (How to correctly assess the 30 years before and since reform and opening), http://dangshi.people.com.cn/n/2013/ 0219/c85037-20530313.html. Accessed 4 June 2015.

Mi, Hedu. 2013. Kong Dan koushu: nan de bense ren tianran (An Oral History of Kong Dan: It's Hard to Be Frank). Hong Kong: Zhonggang chuanmei chubanshe.

Nanzhou gengzheng. 2014. "Jiyi zhi jia" (Home of remembrance), http://zhenhua.163.com/14/0505/ 17/9RGFVU3P000465TM_all.html. Accessed 4 June 2015.

Sachs, Albie. 2014. Duanbi shang de huaduo: rensheng yu falü de qihuan lianjinshu (The Strange Alchemy of Life and Law) (Chen Shuji and Chen Ligong (trans.)). Guilin: Guangxi shifan daxue chubanshe.

Shidai Jianbing. 2014. "Wang Jingyao jujue daoqian de mudi shi yingshe Mao Zedong" (Wang Jingyao rejects that the objective behind the apology is to implicate Mao Zedong), http://www. wyzxmk.com/Article/zatan/2014/02/313478.html. Accessed 4 June 2015.

Song, Binbin. 2012. "Sishi duo nian lai wo yizhi xiang shuo de hua" (What I have been wanting to say for 40 years). Jiyi 80(31 January), 3-15, http://www.xujuneberlein.com/Rem80.pdf. Accessed 4 June 2015. 
Song, Binbin. 2014. "Wo de fansi" (Coming to terms with my past). Jiyi 106(15 January), 31-37, http://www.xujuneberlein.com/Rem106.pdf. Accessed 4 June 2015.

Tutu, Desmond. 2014. Meiyou kuanshu jiu meiyou weilai (No Future without Forgiveness) (Jiang Hong (trans.)). Guilin: Guangxi shifan daxue chubanshe.

Walder, Andrew. 2009. Fractured Rebellion. The Beijing Red Guard Movement. Cambridge, MA: Harvard University Press.

Walder, Andrew. 2015. China under Mao. A Revolution Derailed. Cambridge, MA: Harvard University Press.

Wang, Jingyao. 2014. "Guanyu Song Binbin, Liu Jin xuwei daoqian de shengming” (Statement about the false apology of Song Binbin and Liu Jin), 21 ccom.net, 31 January, http://www.21ccom.net/ articles/lsjd/lsjj/article_2014013099870.html. Accessed 4 June 2015.

Wang, Tinglian. 2009. "'Liang ge sanshi nian,' weihe bu neng xianghu fouding" (Why the "two 30 years" cannot negate each other), http://theory.people.com.cn/GB/40537/9865402.html. Accessed 4 June 2015.

Wang, Youqing. 2004. Wenge shounanzhe (Victims of the Cultural Revolution), http://www.edubridge. com/erxiantang/12/victim_ebook_070505.pdf. Accessed 22 June 2016.

Wang, Youqin. 2014. "Huiying Song Binbin deng" (Responding to Song Binbin and others), 21ccom.net, 26 March, http://www.21ccom.net/articles/lsjd/lsj]/article20140326103090.html. Accessed 4 June 2015.

Weigelin-Schwiedrzik, Susanne. 2006. "In search of a master narrative for 20th-century Chinese history." The China Quarterly 188, 1070-91.

Weigelin-Schwiedrzik, Susanne. 2008. "Coping with the Cultural Revolution: contesting interpretations." Zhongyang yanjiuyuan jindaishi yanjiusuo jikan 61, 1-52.

Wenhua Hong Weibing. 2014. "Yiwan fuhao gaogan zidi wei shenme lülü shangyan 'wenge daoqian' naoju" (Why are so many off-spring of high-level cadres repeatedly playing out the farce of "Cultural Revolution apologies"?), http://club.china.com/data/thread/1011/2767/33/16/7_1.html. Accessed 4 June 2015.

Wu, Di. 2014a. "Song Binbin daoqian zhi hou" (After Song Binbin apologized), The New York Times (Chinese Version), 17 July, http://cn.nytimes.com/china/20140717/cc17sbb/zh-hant/. Accessed 4 June 2015.

Wu, Di. 2014b. "He Wu Di duihua: guanyu wenge de jiyi" (A dialogue with Wu Di: the memory of the Cultural Revolution), The New York Times (Chinese Version), 17 July, http://cn.nytimes.com/ china/20140717/cc17wudiqa/zh-hant/. Accessed 4 June 2015.

Xu, Xinhua. 2011. Sanjiji (Collection of Three Memories). Beijing: Kexue chubanshe.

$\mathrm{Xu}$, Youyu. 1999. Xingxing sese de zaofan. Hongweibing jingshen sushi de xingcheng jiqi yanbian (All Kinds of Rebellion. The Emergence of the Red Guard Mentality and its Development). Hong Kong: Hong Kong Chinese University Press.

$\mathrm{Xu}$, Youyu. 2014. "Chongqing moshi he wenhua da geming - wenge fansi zhi yi" (The Chongqing model and the Cultural Revolution - rethinking the Cultural Revolution). Zuotian $32(30$ March), http://prchistory.org/wp-content/uploads/2014/08/2014\%E5\%B9\%B43\%E6\%9C $\% 8830 \%$ Е6\%97\%A5\%Е7\%AC $\%$ AC32\%E6\%9C $\% 9 \mathrm{~F} \% \mathrm{EF} \% \mathrm{BC} \% 88 \% \mathrm{E} 5 \% \mathrm{~A} 2 \% 9 \mathrm{E} \% \mathrm{E} 5 \% 88 \% 8 \mathrm{~A} \% \mathrm{EF} \% \mathrm{BC}$ \%89.pdf. Accessed 22 June 2016.

Yang, Guobin. 2007. “'A portrait of martyr Jiang Qing': the Chinese Cultural Revolution on the internet." In Ching Kwan Lee and Guobin Yang (eds.), Re-envisioning the Chinese Revolution. The Politics and Poetics of Collective Memories in Reform China. Stanford, CA: Stanford University Press, 287-316.

Ye, Weili. 2014. "Cong 'ba wu' shuoqi" (Talking about "5 August”). Jiyi 106(15 January), 13-18, http://www.xujuneberlein.com/Rem106.pdf. Accessed 4 June 2015.

Ye, Weili, and Xiaodong Ma. 2005. Growing Up in the People's Republic of China. New York: Palgrave MacMillan.

Zhu, Guimu. 2013. “Waimei: Xi Jinping 'liangge sanshi nian lilun' huo shou Deng Liqun zhinang yingxiang" (Foreign media: Xi Jinping's [theory] on "the two 30 years" probably was influenced by Deng Liqun's think tank), http:// http://news.takungpao.com/mainland/focus/2013-06/1716441. html. Accessed 20 June 2015. 